\title{
The Comparative Sociology of Legal Doctrine: Thoughts on a Research Program
}

\author{
Christian Boulanger* (1)
}

(Received 07 September 2020; accepted 13 September 2020)

\begin{abstract}
In the context of the encounter of UK and German socio-legal studies in this issue, this Article develops preliminary thoughts on a research agenda for the comparative interdisciplinary empirical study of legal doctrine. Based on a working definition of doctrine as an institutionally legitimized practice of making statements on the law, it presents an overview of sociological and comparative theorizing about doctrine in Germany, and of the data and methods being used to study it, in order to identify similar or diverging trends in the UK and elsewhere. This Article aims to show that legal doctrine, which is often regarded by non-lawyers as arcane and/or tedious, is an interesting and important subject for comparative socio-legal research.
\end{abstract}

Keywords: legal doctrine; jurisprudence; socio-legal studies; sociology of law; legal academics

\section{A. Introduction}

Socio-legal studies ${ }^{1}$ as an academic pursuit cannot be understood without its "other"- the doctrinal study of law - and vice versa. The relationship between these different perspectives on the law has varied over time and has developed in disparate ways across the globe. A comparison of Germany and the UK is an example of this: Whereas in the UK, Socio-legal Studies have a relatively strong presence in the law schools, German Rechtssoziologie has not been able to gain substantial ground in law schools nor in other departments. ${ }^{2}$ Often, the relationship between doctrinal and non-doctrinal study of the law has been strained. ${ }^{3}$ Ever since Kelsen argued with Ehrlich over the right way to do Rechtswissenschaft, the "science of the law," many scholars on both sides have been accusing the other of not understanding what the law is really about. ${ }^{4}$

${ }^{*}$ Christian Boulanger is the Academic Coordinator of the interdisciplinary Research Network "Law in Context" at Humboldt-Universität zu Berlin. He previously studied Modern History, Law and Political Science in Heidelberg, Berlin and Seattle. He also has a PhD in Political Science from Freie Universität Berlin.

${ }^{1}$ As explained in the introduction to this Special Issue, the term is used here as an umbrella concept for the various forms of the empirical study of the law, whether they are institutionally recognized academic disciplines or intellectual movements within the established disciplines.

${ }^{2}$ See Machura, Milestones and Directions: Socio Legal Studies in Germany and the United Kingdom, in this issue. On the relationship between sociological and doctrinal approaches to law in Germany, see Julika Rosenstock, Tobias Singelnstein \& Christian Boulanger, Versuch über das Sein und Sollen der Rechtsforschung, in INTERDISZIPLINÄRE RECHTSFORSCHUNG 3-29 (Christian Boulanger, Julika Rosenstock, \& Tobias Singelnstein eds., 2019).

${ }^{3}$ For the UK, see generally Neil Duxbury, A Century of Legal Studies, in THe OXFord HANDBook OF LeGAL STUDIES 950-74 (2005). For Germany, see generally Alfons Bora, Sociology of Law in Germany: Reflection and Practice, 43 J.L. \& Soc'Y 619-46 (2016).

${ }^{4} \mathrm{An}$ excellent summary of this debate at the beginning of the $20^{\text {th }}$ century can be found in HANS KELSEN UND DIE Rechtssoziologie: Auseinandersetzungen mit Hermann U. Kantorowicz, Eugen Ehrlich und Max Weber (Stanley L. Paulson ed., 1992).

(c) The Author(s), 2020. Published by Cambridge University Press on behalf of the German Law Journal. This is an Open Access article, distributed under the terms of the Creative Commons Attribution licence (http://creativecommons.org/licenses/by/4.0/), which permits unrestricted re-use, distribution, and reproduction in any medium, provided the original work is properly cited. 
This rift might be the reason that the doctrinal study of law has received surprisingly little attention from socio-legal scholars. ${ }^{5}$ Though vivid, the often-used distinction between the "law on the books" and the "law in action" is unhelpful in this respect, as long as it conjures the image of a body of text on paper- "black-letter law"-which is largely irrelevant for the "real" law out there in society. This Article argues that it is precisely the connection between law on the books and the law in action that makes studying legal doctrine, from a sociological and comparative perspective, in its various forms worthwhile. Instead of looking at doctrine as the antithesis of their work, socio-legal scholars might gain insight about the social mechanisms of legal knowledge production. As a side effect, this research focus might help enhance collaboration between doctrinal and non-doctrinal scholars because both sides are necessary for this endeavor to be successful.

When I speak of "doctrine," I use this term as "legal dogmatics," which would be etymologically closer to the German Rechtsdogmatik although it is much less commonly used. ${ }^{6}$ Both "doctrine" (from Latin doctrina) and its continental sibling concepts that are derived from the Greek dogma have a double etymology that provide notions of both craftsmanship and religious orthodoxy. ${ }^{7}$ The traditional German understanding of statute-based Rechtsdogmatik has been defined as the "academic study of the law," which expresses the close connection of German doctrine to legal scholarship. In the UK, doctrine has been defined to express "authoritative juridical ideas that may direct the course of legal decisions," which hints at the high influence of courts in the development of doctrinal statements. It is clear that "doctrine" is what lawyers deal with and that it goes beyond positive law. As I will argue in Section D, a socio-legal analysis of doctrine will look beyond ideas and texts and look at social practices of making statements about what the law is - within the institutions-giving these statements authority and legitimacy.

The following sections present some preliminary thoughts on one of many possible research agendas for the comparative empirical study of legal doctrine. After a short survey on the state of the art, I will justify why it is important to look more closely at legal doctrine, provide a working definition of doctrine as an institutionally legitimized practice of making statements on the law, and give an overview about empirical theorizing about doctrine and about data and methods that are being used to study doctrine in Germany. In line with the exploratory character of the workshop that gave rise to this Special Issue and the early stage of my project, ${ }^{10}$ this Article does not attempt to give a comprehensive picture of existing research. Instead, I will be focusing on a few exemplary lines of research in Germany to show that there is a lot to be learned by looking at doctrine from a sociological perspective. My hope is to contribute conceptually to a future Sociology of doctrine which is done comparatively-with attention to the social, political, and historical context-while using international and interdisciplinary collaboration.

\footnotetext{
${ }^{5}$ See Section B, below.

${ }^{6}$ The Google Books Ngram Viewer shows almost no occurrences of "legal dogmatics" until the mid-1970s, with a peak in the mid-1980s, but even then "legal doctrine" occurs five times more frequently. See Google, Google Books Ngram Viewer, https://tinyurl.com/y7j9erjy (last visited May 23, 2020).

${ }^{7}$ The meaning of the original Latin and Greek terms refer to teachings or to established rules of a craft, for example, in medicine. In early Christian Theology, doctrina and dogma continued to be understood as teachings or decisions-based on the exegesis of biblical texts - that answered a specific question. The modern connotation of officially ordained truths that are not to be questioned - expressed, for example, in the term "dogmatism" — was only a later development. See MAXIMILIAN Herberger, Dogmatik: zur Geschichte von Begriff und Methode in Medizin und Jurisprudenz (1981). For uses of "doctrine" in English legal history, see Joshua Getzler, Legal History as Doctrinal History, in THE OXFORD HANDBOOK OF Legal History 1 (Markus D. Dubber \& Christopher Tomlins eds., 2018).

8"Die rechtswissenschaftliche Bearbeitung des Rechts nennt man Rechtsdogmatik." Christian Starck, Die Bedeutung der Rechtsdogmatik für die Rechtsvergleichung, in RECHTSVERGLEICHUNG-SPRACHE-RECHTSDOGMATIK 11 (Frank Schorkopf \& Christian Starck eds., 2019).

${ }^{9}$ Getzler, supra note 7 , at 2 .

${ }^{10}$ This Article was motivated by the workshop and written afterwards, which did not leave enough time to integrate a survey of the UK research landscape.
} 


\section{B. An Emerging Research Program on Empirical and Comparative Study of Doctrine}

In a 2004 article, Ingo Schulz-Schaeffer remarks that Sociology of law has, "from the beginning up to today, shown very little interest for the doctrinal study of law, i.e. the practice of interpretation of the codified positive law in jurisprudence (Jurisprudenz)." ${ }^{11} \mathrm{He}$ cites a similar diagnosis to that of Niklas Luhmann in 1986, where he finds Luhmann's statement that "there is no adequate Sociology of legal doctrine"12 still holds. Schulz-Schaeffer found it bewildering that the empirical study of a social field such as law would almost completely disregard what most legal scholars, and certainly those in Germany, consider the "core" of their enterprise. ${ }^{13}$

Another sixteen years later, have things changed? There is little evidence that it has, at least in a systematic way. No German textbook on the Sociology of law treats Rechtsdogmatik in depth-mostly, it serves as a reference point for what the Sociology of law is not. ${ }^{14}$ In the UK, the situation seems not much different. The debates which have been held in the last few decades on the question as to whether "doctrinal legal studies" have academic credentials at all, ${ }^{15}$ have produced a number of important studies that reflect on the social practice of the production of legal doctrine. ${ }^{16}$ However, there seems to be no systematic empirical research on legal doctrine itself. ${ }^{17}$ Therefore, it is not surprising that, given this gap in research at the national level, systematic comparative empirical research on the subject is hard to come by. ${ }^{18}$

A major challenge for this research is that it is quite unclear what terms like Rechtsdogmatik, ${ }^{19}$ la doctrine, ${ }^{20}$ or legal doctrine/dogmatics/jurisprudence actually refer to when seen from a comparative perspective. One indication of this is the quote by Schulz-Schaeffer above, whose definition of the doctrinal study of law as "the practice of interpretation of the codified positive law in jurisprudence" does not work very well in common law jurisdictions such as England, Wales, or the U.S. ${ }^{21}$ There, "doctrine" is mainly equated with judicial lawmaking, ${ }^{22}$ while "doctrinal analysis" means, in the majority of cases, the examination of "the content of a legal opinion to evaluate whether it was effectively reasoned or to explore its implications for future cases." ${ }^{.3}$ Even if the importance of statutory law has been steadily increasing, the main debate seems to center on

\footnotetext{
${ }^{11}$ Ingo Schulz-Schaeffer, Rechtsdogmatik als Gegenstand der Rechtssoziologie: für eine Rechtssoziologie "mit noch mehr Recht," 25 ZEITSCHRIFT FÜR RECHTSSOZIOlOGIE 141, 141 (2004) (author translation).

${ }^{12}$ Admittedly, Luhmann would not consider any sociological theory on the subject to be theoretically "adequate" unless it were derived from System Theory.

${ }^{13}$ See Susan Bartie, The Lingering Core of Legal Scholarship, 30 LEGAL STUD. 345, 345-69 (2010); Martin Eifert, Zum Verhältnis von Dogmatik und pluralisierter Rechtswissenschaft, in WAS WEIß DOGMATIK? 79-96 (Gregor Kirchhof, Stefan Magen \& Karsten Schneider eds., 2012).

${ }^{14}$ See, e.g., MANFred ReHbinder, Rechtssoziologie 1 (8th ed. 2014).

${ }^{15}$ On this debate, see Bartie, supra note 13. See also Geoffrey Samuel, Is Law Really a Social Science? A View from Comparative Law, 67 The CAMBRIDGe L.J. 288 (2008).

${ }^{16}$ Most notably, of course, Fiona Cownie's seminal study on legal academics. FIONA Cownie, LEGAL ACADEMICS: CULTURE AND IDENTITIES (2004).

${ }^{17}$ Unlike in the United States, where empirical studies on legal doctrine has existed for some time now. See, e.g., Emerson H. Tiller \& Frank B. Cross, What Is Legal Doctrine?, 100 Nw. UnIV. L. Rev. 517 (2006); Jessie Allen, Empirical Doctrine, 66 CASE W. RES. L. ReV. 1 (2015).

${ }^{18}$ At least such research is not reflected in handbooks that reflect the state of the art in the discipline. See, e.g., COMPARATIVE LAW AND SOCIETY (David Scott Clark ed., 2012).

${ }^{19}$ Rolf Gröschner, Rechtsdogmatik, in HANDBUCH RECHTSPHILOSOPHIE 61-66 (Eric Hilgendorf \& Jan C. Joerden eds., 2017).

${ }^{20}$ Horatia Muir Watt, The Epistemological Function of 'la Doctrine,' in METHOdOLOGIES of LEGAL ReSEARCH: WHAT Kind of Method for What Kind of Discipline? 123-32 (Mark Van Hoecke ed., 2011).

${ }^{21}$ The "mixed system" in Scotland is a special case. See Stephen Thomson, Mixed Jurisdiction and the Scottish Legal Tradition: Reconsidering the Concept of Mixture, 7 J. CIV. L. STUD. 51 (2014).

${ }^{22}$ See, for example, Edward Rubin \& Malcolm Feeley, Creating Legal Doctrine, 69 S. CAL. L. Rev. 1989 (1995).

${ }^{23}$ Tiller \& Cross, supra note 17 , at 518.
} 
the role of judicial precedent in determining the law of the land. ${ }^{24}$ It is clear that doctrine is about making authoritative statements about the law, but it is less clear what this entails in practice, and what the role of courts, legal scholarship, and lawyers in general is within this practice. The ambiguity of the term "doctrine" is not due to "the lack of a supra-jurisdictional lingua franca." ${ }^{25}$ The problem is more fundamental. As I will argue, national forms of "doctrine" are not primarily systems of thought, but institutionally framed social practices inseparably connected with temporal-spatial social context of the individual nations.

The challenge of undertaking comparative empirical research on doctrine is thus threefold. First, given the multiplicity of concepts, we need to find a suitable "sociological concept" of "doctrine," which will work across legal cultures and histories and which can be operationalized in very different contexts. If such a concept can be found, the second challenge is to define the comparative "research questions." It is to be expected that the questions researchers are interested in will differ substantively in terms of their legal and academic context, because both the normative and empirical studies of law have very different trajectories in different countries. ${ }^{26}$ Third, given the vast array of theoretical approaches and empirical methods available to social scientists, such a research program will have to decide on the right mix of these "theories and methods"-determining which will best serve to answer the research questions. It seems plausible to assume that no single theory or method will be sufficient.

These challenges are further complicated by the fact that such a research program is by definition an interdisciplinary enterprise that involves social scientists as well as lawyers. ${ }^{27}$ Fortunately, it seems that today, the unproductive antagonisms of the past are slowly being overcome. ${ }^{28}$ Legal and socio-legal researchers—-at least in both disciplines' cutting edge research-are taking each other seriously and are working together to better understand "the force of law." 29 Despite this, significant differences remain in the kind of questions legal and socio-legal scholars are interested in, how they define problems and concepts, and what kind of methods they are trained in and which they find relevant to their research questions. ${ }^{30}$

Such a project, I argue, needs input from many disciplines. First, it should entail a strong historical component. The great variety of legal systems and cultures makes it obvious that law is a historically contingent, path-dependent phenomenon. ${ }^{31}$ The specific form in which a practice of legal doctrine can be observed in a particular legal system and geographic area is thus a consequence of lengthy historical developments that shape discourses and thought patterns. The social practice of legal doctrine is subject to constant change, whereby the interesting question

\footnotetext{
${ }^{24}$ Ugo Mattei \& Luca G. Pes, Civil Law and Common Law: Toward Convergence?, in The OxFORD HANDBOOK OF LAW AND Politics (Gregory A. Caldeira, R. Daniel Kelemen \& Keith E. Whittington eds., 2008). This is not a critique of SchulzSchaeffer's article-as he is explicitly focusing on German Sociology of law and German doctrine.

${ }^{25}$ Duxbury, supra note 3, at 968.

${ }^{26}$ See Jennifer Hendry, Naomi Creutzfeldt \& Christian Boulanger, Socio-Legal Studies in Germany and the UK: Theory and Methods, in this issue.

${ }^{27}$ This mirrors the demands on the side of legal scholars that their doctrinal research should involve non-doctrinal scholarship, which effectively means communicating with social scientists. See generally Matyas Bodig, Legal Doctrinal Scholarship and Interdisciplinary Engagement, 8 ERASMUs L. REV. 43 (2015).

${ }^{28}$ But see Samuel, supra note 15.

${ }^{29}$ See generally Pierre Bourdieu, The Force of Law: Towards a Sociology of the Juridical Field, 38 HASTINGs L.J. 814 (1987). For a less optimistic view about the cooperation between lawyers and scientists, see generally Reza Banakar, Law Through Sociology's Looking Glass: Conflict and Competition in Sociological Studies of Law, in THE ISA HANDBOOK IN CONTEMPORARY Sociology 58-73 (Ann Denis \& Devorah Kalekin-Fishman eds., 2009).

${ }^{30}$ On methods in the UK and other English-language research contexts, see generally NAOMI CREUTZFELDT, Traditions of Studying the Social and the Legal, in Routledge Handbook of Socio-Legal Theory ANd Methods 9-34 (Naomi Creutzfeldt, Marc Mason \& Kirsten McConnachie eds., 2019).

${ }^{31}$ On path dependence and institutional analysis, see generally PAUl PiERSON, POLITICS IN Time: History, Institutions, And Social Analysis (2004). See also Oona A. Hathaway, Path Dependence in the Law: The Course and Pattern of Legal Change in a Common Law System, 86 IowA L. Rev. 601 (2000).
} 
concerns which elements remain constant over a long period of time and which elements must be adapted to social developments. Thus, any research on these differences must include insights from legal history, in particular the socio-historical study of the legal method. Luckily, we can build on a large body of historical-comparative work on the development of doctrinal practices. $^{32}$

We also need to involve and integrate the knowledge about legal doctrine that exists in the research field of comparative law. Comparative lawyers know that, without knowledge of contextual factors such as "legal culture, legal argumentation, judicial decision making, styles of legal writing, diverging approaches to legal sources and to statutory interpretation (e.g., the use of travaux préparatoires), the role of legal doctrine, the respective role of the legal professions, the role of form in law in relation to substance," 33 any comparison between laws and legal systems will be deficient. Additionally, there is increasing interest in connecting comparative law with socio-legal theory and methods. ${ }^{34}$ However, if the Oxford Handbook of Comparative Law is any indication of the current state of the art, it seems like the phenomenon of doctrine or, in a broader sense, the legal method, is not regarded as a topic that requires a separate chapter. ${ }^{35}$

\section{Why Comparing Legal Doctrine is Important}

Identifying a gap in research says little about its relevance. Why should we study doctrinal practices beyond the fact that it is still possible to say something new? One reason is that from a sociological perspective, legal doctrine is about the power to make decisions. Lawyers and legal scholars use doctrinal arguments in their attempt to influence, inter alia, administrative agencies and the courts, and judges use it to justify their decisions. This has two implications: An analytical one that concerns academic theory development, and a "critical legal studies" one concerning the social and political legitimacy of doctrinal power.

Some proponents of legal realism have claimed that doctrinal argumentation amounts to a post-hoc rationalization for what are arbitrary political or other value choices. ${ }^{36}$ In the tradition of the legal realists, some scholars in U.S. Political Science research have been almost obsessively studying the Supreme Court judgments with the aim of demonstrating that the impact of

\footnotetext{
${ }^{32}$ In Germany, Stefan Vogenauer has produced extensive historical and comparative work on Germany and the UK. See generally STEFAN Vogenauer, Die AUSLEGUNG VON GESETZEN In ENGLAND UND AUf DEM KONTINENT: EINE VERGLEICHENDE

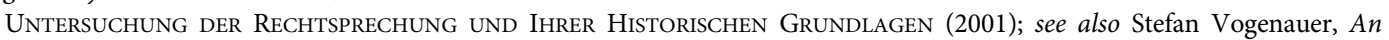
Empire of Light? Learning and Lawmaking in the History of German Law, 64 THE CAMBRIDGE L.J. 481 (2005) (providing an English language summary on the German history). In English, one usually finds references to the classic comparative treatises by John Philip Dawson, The Oracles of the Law (1968) and by Raoul C. Van Caenegem, Judges, Legislators and Professors: Chapters in European Legal History (1987).

${ }^{33}$ Mark Van Hoecke, Methodology of Comparative Legal Research, in LAW AND METHOD (2015). On the history of comparative law methods, see Günter Frankenberg, Critical Histories of Comparative Law, in THE OXFORD HANDBOOK OF LEGAL History (2018).

${ }^{34}$ See Annelise Riles, Comparative Law and Socio-legal Studies, in The Oxford Handbook of Comparative LAW (Reinhard Zimmermann \& Mathias Reimann eds., 2006); Naomi Creutzfeldt, Agnieszka Kubal \& Fernanda Pirie, Introduction: Exploring the Comparative in Socio-legal Studies, 12 INT'L J.L. CONTEXT 377 (2016); Michelle Cottier, Interdisziplinäre Rechtsvergleichung, in INTERDISZIPLINÄRE RECHTSFORSCHUNG 109-23 (Christian Boulanger, Julika Rosenstock \& Tobias Singelnstein eds., 2019).

${ }^{35}$ The subject is touched on in the chapter on "Sources of Law and Legal Method." Stefan Vogenauer, Sources of Law and Legal Method in Comparative Law, in The Oxford Handbook of Comparative Law 870-99 (Reinhard Zimmermann \& Mathias Reimann eds., 2006).

${ }^{36}$ For an exposition of this claim, see generally Mark Tushnet, Legal Scholarship: Its Causes and Cure, 90 YALE L.J. 1205 (1980) (outlining a brilliant polemic about this claim). For a response, see Lawrence B. Solum, On the Indeterminacy Crisis: Critiquing Critical Dogma, 54 The Univ. of Chicago L. Rev. 462 (1987).
} 
"legal" factors is insignificant in explaining the court's rulings, compared to ideological and strategic considerations. ${ }^{37}$ No matter how convincing one finds radical or simplified versions of the legal indeterminacy thesis, legal realists' annihilation of law's pretenses to be an objective "science" has, by now, been almost universally accepted, irrespective of the conclusions that one draws from that insight. ${ }^{38}$ Many scholars do not believe that doctrine is simply a smokescreen for "something else," at least not in all cases. Instead, their data points them to the assumption that doctrine does actually influence the behavior of judicial or other actors by constraining, or positively influencing, the available outcomes. ${ }^{39}$ From a sociological perspective, it is necessary to clarify how the knowledge about "what the law is" is produced, and what social mechanisms are at play when doctrinal practices are involved in the social construction and reproduction of legal knowledge. This goes beyond simply stating causal effects evidenced by statistical correlations in our data, as valuable as such empirical knowledge is. Socio-legal scholars are typically also interested in how those empirical insights fit into existing social-scientific theorizing. In addition, the picture we will get will be very complex, and we can expect each area of law to function very differently-criminal law's doctrinal practices are different from public law's, and, say, family law and commercial law are worlds apart. There will be empirical cases where doctrine truly is nothing but a rationalization of extra-legal motivations; in other cases, we might find that it actually constrains the range of possible legal outcomes.

In contrast, the "critical legal studies" aspect concerns the fact that looking at what lawyers do or say is not just a special application of the Sociology of knowledge or the Sociology of professions. ${ }^{40}$ Rather, it leads to the question of how much influence the legal profession has on central political and social decisions, and to what extent this influence can be justified —or instead-in what respects this influence has to be criticized. Thus, the question about how legal knowledge is produced also becomes a problem of democratic theory and the rule of law. ${ }^{41}$ It needs to be empirically analyzed, not with the primary aim of "unmasking" and debunking its pretenses, but of making its mechanisms transparent and open for critical discussion. As Dieter Grimm has argued, if a legal norm finds its final form not at the time of its entering into force, but at the time of its application in a specific case, then the rules and metarules of its application are as important as the

\footnotetext{
${ }^{37}$ For classic works on this see generally Segal \& SpaEth, The Supreme Court and the Attitudinal Model (1993); Segal \& Spaeth, The Supreme Court and the Attitudinal Model Revisited (2002); Epstein \& Knight, The Choices JustiCES MAKE (1998).

${ }^{38}$ Duxbury, supra note 3; Brian Z. Tamanaha, Understanding Legal Realism, 87 TEx. L. REv. 731 (2008). The legal realists in the United States were not the first to point this out, but their influence on legal thinking was much stronger than that of their precursors and counterparts in Europe. See also Klaas Hendrik Eller, Comparative Genealogies of "Contract and Society," in this issue. In Germany, the "scientific" basis of "legal science" is still an important topic. See, e.g., HeLMUTH SCHUlzE-FIELITZ, STAATSRECHTSLEHRE ALS WisSENSCHAFT (2017).

${ }^{39}$ More recently, some protagonists in U.S. political science research on judicial behavior have called for revisiting some of the main assumptions of this literature. They have hinted at the possibility that one of the factors motivating judges might, after all, be "a simple desire to 'follow the law." See Lee Epstein \& Jack Knight, Reconsidering Judicial Preferences, 16 ANN. REV. POL SCI. 11, 25 (2013). See also Daniel L. Chen, Jens Frankenreiter \& Susan Yeh, Judicial Compliance in District Courts (2017), Available at https://papers.ssrn.com/abstract=2740594 (last visited Apr. 27, 2020); Tiller \& Cross, supra note 17; Frank B. Cross \& Emerson H. Tiller, Judicial Partisanship and Obedience to Legal Doctrine: Whistleblowing on the Federal Courts of Appeals, 107 Yale L.J. 2155 (1998).

${ }^{40}$ This is Luhmann's reservation against the study of judicial behavior or the legal profession. See NIKLAS LUHMANN, Rechtssoziologie 3-9 (1972).

${ }^{41}$ See generally Liza Mattutat, Das Problem der Unbestimmtheit des Rechts - Konsequenzen für die theoretische und die praktische Rechtskritik, KRITISCHE JusTIZ 496-508 (2016). See also Tushnet's claim that because of the indeterminacy of law, the "rule of law" is nothing but untenable liberal ideology. Tushnet, supra note 36. On Critical Legal Studies, see generally Roberto Mangabeira Unger, The Critical Legal Studies Movement, 96 Harv. L. Rev. 561 (1983) (the canonical article on the subject), although critiques of doctrinal truth-claims are not limited to the political left, as the example of Carl Schmitt shows. William E. Scheueman, The End of Law: Carl Schmitt in the Twenty-First Century (2d ed. 2019).
} 
norm itself. ${ }^{42}$ As the method of interpretation can drastically change the meaning of a legal rule, it is not surprising that, as Grimm points out, most important debates in German jurisprudence have concerned themselves with methods rather than substantive content. ${ }^{43}$ The power to interpret legal norms ${ }^{44}$ implies the power to choose the rules of interpretation. This power is always shared with the community to which doctrinal texts are addressed, because the approval of this audience is critical to the authority of the interpreter. ${ }^{45}$ However, the takeaway is that when we are talking about doctrine, we are always also talking about power issues. This is obvious in high-level cases in apex courts on a national or international level, but equally true for lower-level courts, ${ }^{46}$ or questions of legal education ${ }^{47}$ or career paths in legal academia. ${ }^{48}$

\section{Legal Doctrine as Institutionally Legitimated Practice}

Before turning to the questions that a comparative inquiry might address, it is necessary to define the concept of doctrine that such an inquiry might be based upon. As comparative lawyers know, the use of one's own vocabulary to describe a different legal system is highly problematic. The same is true for a socio-legal approach. One can introduce a new, alien vocabulary, as System Theory does, to get rid of historical and cultural connotations. ${ }^{49}$ Another option is to redefine the existing one-with Max Weber as the obvious example $e^{50}$. The advantage with the latter approach is that the resulting analysis is more accessible, in particular when dealing with an interdisciplinary audience, and that approach is chosen for this Article. However, it is important to keep in mind that one has to distinguish between the analytical concept of doctrine as used in this Article to cover doctrinal practices in general, and the term as it is used when describing actual "doctrine" as it is understood in various English-language legal systems.

In contrast to legal philosophy, a sociological perspective will define terms that refer to observable practices that go beyond the systems of thought that are communicated mainly through printed texts. Texts are the outcome of a whole chain of events in which actors do something; ideas are developed and communicated in social contexts which make some ideas easier to express than others. ${ }^{51}$ Doctrinal practice usually requires making arguments that are considered to be

\footnotetext{
${ }^{42}$ Dieter Grimm, Methode als Machtfaktor, in EuropäISCHES ReCHTSDENKEN IN GESCHICHTE UND GEGENWART 469,470 (Norbert Horn ed., 1982).

${ }^{43} \mathrm{~A}$ vivid example is the principle of proportionality, which was developed in nineteenth century administrative law, to experience a remarkable career in German constitutional law and European Union law. Moshe CoHEN-ELIYA \& IDDO Porat, Proportionality and constitutional culture (2013). Because it allows courts to control the rationality of political decisions, it was fiercely opposed by parts of legal scholarship who defended the discretion of governmental decisionmakers and/or the sovereignty of parliament.

${ }^{44}$ For recent discussions of this power in German political science, see generally Hans Vorländer, Deutungsmacht-Die Macht der Verfassungsgerichtsbarkeit, in Die Deutungsmacht DeR Verfassungsgerichtsbarkeit (Hans Vorländer ed., 2006).

${ }^{45}$ Lawrence Baum, Judges and Their Audiences (2006); Nuno Garoupa \& Tom Ginsburg, Judicial Audiences and Reputation: Perspectives from Comparative Law, 47 Colum. J. TransNAT'L L. 451 (2011).

${ }^{46}$ One classical example from the German literature is RÜDiger Lautmann, Justiz-DiE stille Gewalt: Teilnehmende Beobachtung und EnTSCHEIDUNGSSOZIOlOgische ANALYse (1972).

${ }^{47}$ For example, there are feminist critiques of gender stereotypes in the contrived examples that are used in German law schools to teach students how to solve legal cases. See generally Dana-Sophia VAlEntiner, (GESCHLECHTER) ROLLENSTEREOTYPe IN JURISTISCHEN AusbiLdUngSFÄLlEN (2017). For a critical view on legal education, see also Sonja Buckel, Die Mechanik der Macht in der juristischen Ausbildung, 35 KRITISCHE JUsTIZ 111-14 (2002).

${ }^{48}$ Fiona Cownie, Legal Academics: Culture and Identities (2004).

${ }^{49}$ Niklas Luhmann, Law as a Social System (Klaus A. Ziegert \& Fatima Kastner trans., 2008).

${ }^{50}$ For a look at his "Basic Sociological Terms" or the ideal types of "Formal and Substantive Rationalization" in law, see MAX WEBER, ECONOMY AND SOCIETY (Guenther Roth \& Claus Wittich eds., 1978).

${ }^{51}$ Michel Foucault, in particular, stressed this point. On the uses and the limits of Foucauldian discourse theory for sociolegal research, see Doris Schweitzer, Diskursanalyse, Wahrheit und Recht: Methodologische Probleme einer Diskursanalyse des Rechts, 35 ZEITSCHRIFT FÜR RECHTSSOZIOLOGIE 201 (2015).
} 
"legal" by the local epistemic community of lawyers ${ }^{52}$ at a particular place and time. In all instances, "the normative content of any doctrine will fall to be determined by the dynamic interpretation of the legal community." 53

This is why I argue that from a sociological perspective, doctrine refers to institutionally legitimized practices of making statements on what the law is. Defining doctrine as "making statements on what the law is" is hardly original and probably not controversial. The stress here is on "institutionally legitimized," because it signals the context-sensitivity of the approach. The form and behavior of legal institutions varies significantly in different locations, as do the ways these institutions confer legitimacy - in its empirical sense-on its members to make authoritative statements. This way of understanding doctrine as a social practice is general enough to cover the very distinct legal cultures in the UK and Germany without claiming to provide a universal definition. ${ }^{54}$

Doctrinal practices can be observed in judicial decision-making, in legal advocacy, and in legal scholarship. Each use involves different, but partly overlapping, institutionalized contexts: The judicial system, the market for legal services, and the academy. The first form has been thoroughly studied in the U.S. context, with a focus on higher courts, ${ }^{55}$ and with the qualification that the "mainstream" research held for a long time that the actual impact of doctrine on judicial decision making was negligible. Lawyers have been a popular research object. ${ }^{56}$ Lawyers use "applied doctrine," ready-made pieces of argumentation that do not have to be consistent as long as they are effective. For them, "legal expertise," which entails much more than strictly legal knowledge ${ }^{57}$ is much more important than the doctrinal quality of their argument. However, recent research on strategic litigation and "cause lawyering"58 sheds a light on the attempts by lawyer activists to influence doctrine in order to change political or social outcomes.

The third form of doctrine, legal scholarship, is developed mainly, but not exclusively, at universities. For Susan Bartie, in the case of the UK, it is controversial to try and "define a 'standard' form of legal scholarship in circumstances where the concept of law and how it ought to be studied has been in a state of constant flux" ${ }^{59}$ Bartie identifies the "core" of doctrinal legal scholarship, or the "concept of 'doctrinalism' or 'black letter law" in the following way: "[F] ocusing on legal principle (largely that generated by courts but also the legislature); basing argument and prescription on a normative premise which is not unpacked or explained; reacting to events comprising of changes to the law by judges or legislators; and, looking for deficiencies in legal principles,

\footnotetext{
${ }^{52}$ On epistemic communities in the context of EU legal integration, see Jennifer Hendry, The Double Fragmentation of Law: Legal System-internal Differentiation and the Process of Europeanisation, in "INTEGRATION THROUGH LAW" REVISITED: THE Making of THE European Polity 157-70 (Daniel Augenstein ed., 2013). In Germany, Britta Rehder has used the concept to study developments in labor law. See Britta Rehder, Rechtsprechung als Politik: Der Beitrag Des

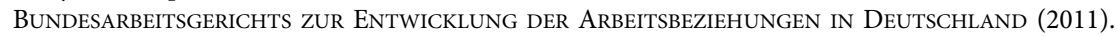

${ }^{53}$ Getzler, supra note 7, at 173 .

${ }^{54}$ Such an understanding is part of what Robert Merton has called "theories of the medium range," which are "theories that lie between the minor but necessary working hypotheses that evolve in abundance during day-to-day research and the allinclusive systematic efforts to develop a unified theory that will explain all the observed uniformities of social behavior, social organization and social change." Robert K. Merton, Soc. Theory and Social Structure 39 (1957). On the difference between normative and empirical legitimacy, see Rodney Barker, Legitimacy: The Identity of the Accused, 42 POL. STUD. 101, 101-02 (1994) (providing a succinct summary on the difference).

${ }^{55}$ The advanced state of research is evidenced by the existence of specialized handbooks such as the ROUTLEDGE HANDBOOK of Judicial Behavior (Robert M. Howard \& Kirk A. Randazzo eds., 2018); and The Oxford Handbook OF U.S. Judicial BeHAVIOR (Lee Epstein \& Stefanie A. Lindquist eds., 1st ed. 2017).

${ }^{56} \mathrm{~A}$ lot of this literature deals with the influence of the legal profession on political outcomes. See Terence C. Halliday, The Politics of Lawyers: An Emerging Agenda, 24 L. \& Soc. INQUIRY 1007, 1007-11 (1999), and Lawyers in 21st-Century Societies (Richard L Abel et al. eds., 2020).

${ }^{57}$ For example, to know which judge is susceptible to what kind of argument. On "legal expertise," see ALEXANDER SOMEK, RECHTLICHES WISSEN (2006).

${ }^{58}$ See, e.g., Lisa Hahn, Strategische Prozessführung, in ZEITSCHRIFT FÜR RECHTSSOZIOLOGIE 5-32 (2019).

${ }^{59}$ Bartie, supra note 13 , at 349.
} 
suggesting ways to improve them or clarifying the law so that judges or legislators can better understand their development." For her, the methodology adopted is "likened to that of the courts with the primary focus resting on the internal logic of judgments or statute[s]." 60

Despite the seemingly stronger continuity and stability of the practice of doctrinal analysis in Germany, no consensus exists about what exactly Rechtsdogmatik means. ${ }^{61}$ German lawyers, when speaking of it, refer to texts—-such as legal decisions, law review articles, commentary literature, or monographs. "Rechtsdogmatik," according to Christian Bumke, "endeavours to sift through and to secure the ideas and insights about the law. To this end, it forms and develops legal concepts or principles and organizes the legal material" 62 for the use in judicial argument and legal education. There is no consensus as to whether positive law is to be considered part of "Rechtsdogmatik." 63

Both descriptions of doctrine hint at the generative, or creative, aspect of doctrinal legal scholarship only in passing. For Bumke, legal dogmatics "forms and develops legal concept or principles" only to the end of systematizing the law that is somehow "out there." Bartie equally portrays doctrinal analysis in the subservient role of a service provider for judges and legislators, which might occasionally make suggestions to improve legal principles. Legal doctrinal scholarship, in its many forms, is not simply reproducing decisions by legislatures and courts, but often "creating" legal principles, interpretative choices, and other normative ideas which are picked up and sanctified as law later on in the courts or in Parliament. As a rule, legal doctrinal texts aim to become part of legal knowledge-meaning they are read and cited by other lawyers. They create new law inasmuch as they do not simply reproduce something given, but make a choice as to what should count as the law. Dogmatic texts contain normative statements that, ultimately, are meant to be used in a judicial decision. In this way, a doctrinal text unfolds social effectiveness in a completely different way than, for example, a political science essay. This aspect of power is usually excluded from legal reflection. In empirical research, however, it is of great importance.

\section{E. The Empirical Study of Legal Doctrine}

How can we go about studying doctrinal practices empirically and comparatively? As I have argued, the Sociology of doctrine is a field of research that has yet to take definitive shape. The aim of this section is to identify, from a bird's eye view, existing theoretical and methodological work which can be brought together in order to advance the state of the art. As my research into the history and present state of this research in the UK is still very much at the beginning, the following observations are limited to a description of some recent developments in theoretical and methodological approaches in the German literature-in order to be able to identify similar research in the UK and elsewhere later. ${ }^{64}$

\section{Theory}

Traditional sociological theory has focused on observable human behavior and has regarded law as an epistemic object. Legal knowledge in this perspective consists of information, practices, discourses, et cetera, which are regarded, "known," and (re-)produced by actors as "legal." The

\footnotetext{
${ }^{60} \mathrm{Id}$.

${ }^{61}$ Martin Eifert, Zum Verhältnis von Dogmatik und pluralisierter Rechtswissenschaft, in WAS WEIß DOGMATIK? 79, 80 (Gregor Kirchhof, Stefan Magen \& Karsten Schneider eds., 2012).

${ }^{62}$ Christian Bumke, Rechtsdogmatik: Überlegungen zur Entwicklung und zu den Formen einer Denk- und Arbeitsweise der deutschen Rechtswissenschaft, 69 JuRISTENZEITUNG 641, 641 (2014).

${ }^{63}$ Rosenstock, Singelnstein, and Boulanger, supra note 2, at 9.

${ }^{64}$ Much more current and past research exists than what I present here. See, e.g., NeUE THEORIEN DES RECHTS (Sonja Buckel, Ralf Christensen \& Andreas Fischer-Lescano eds., 2d ed. 2008).
} 
acting persons - for example judges, lawyers, legal academics, clients, or citizens-approach the law with often antagonistic interests and world views that can be in some way empirically determined or are theoretically presumed.

Max Weber's work falls into this tradition and is still quite influential, both in the social sciences and in the law in Germany. This is not surprising because Weber was a lawyer himself who used concepts from legal doctrine ${ }^{65}$ to analyze the law sociologically. Weber pointed out the societal embeddedness of the law with his concept of "legal thinking," which was not about legal ideas alone, but also how they developed in response to social and economic needs, institutional constraints and incentives, and self-interests of the legal profession. ${ }^{66}$ Weber's ideal typical description of what continental, or more specifically, German, legal doctrine purported to do at the turn of the twentieth century is that "the jurist, taking for granted the empirical validity of the legal propositions, examines each of them and tries to determine its logically correct meaning in such a way that all of them can be combined in a system which is logically coherent, in other words, free from internal contradictions." ${ }^{67}$ For him, this "rational" system of doctrine was the outcome of the monopolization of legal education at the universities. Weber contrasted this type of "legal thinking" with the situation in England, where the "empirical training in the law as a craft training" prevented such rationalization to take place. ${ }^{68}$ At the same time, this form of legal thinking implies contrasting visions of the role of the judge-anonymous legal "automaton" in Germany, charismatic judge in the UK. ${ }^{69}$ Taking into account the deficiencies of a work that is more than one hundred years old, ${ }^{70}$ the basic tenets of Weberian thinking continue to inspire general theorizing and often provide a common ground for lawyers and social scientists. ${ }^{71}$ However, few studies apply Weberian theory for actual empirical research. ${ }^{72}$

In recent years, Pierre Bourdieu's work on law has become influential in German socio-legal studies. ${ }^{73}$ Bourdieu builds on Weber's actor-centered and institutional analysis but adds the idea of the legal "field" in which individuals and groups with different "legal capital" and distinctive forms of "habitus" struggle for hegemony over the authoritative interpretation of the law. In his writings on law, which are exclusively concerned with the French case, the conflictual nature of the legal field is emphasized in a particularly strong manner: It is a matter of struggles over symbols and interpretations, but also over institutional hierarchies and financial resources.

\footnotetext{
${ }^{65}$ For example, note his use of "formal" and "substantive" to categorize types of legal thinking in different religions and parts of the world. See WeBER, supra note 50, at 654.

${ }^{66} I d$. at $654-58$.

${ }^{67} I d$. at 311 . From the context, it becomes clear that Weber does not claim that the legal method would actually bring laws into a logically coherent system. For him, lawyers in the continental European legal act as if this were the case, which has an effect on how the law works.

${ }^{68} \mathrm{Id}$. at 784. It is important to remember that "rational" in the Weberian sense is an analytical, not evaluative term. See generally Duncan Kennedy, The Disenchantment of Logically Formal Legal Rationality or Max Weber's Sociology in the Genealogy of the Contemporary Mode of Western Legal Thought, 55 Hastings L.J. 1031 (2003).

${ }^{69}$ WEBER, supra note 50, at 979, 763. On the notion of a "charismatic judge," see Isher-Paul Sahni, Max Weber's Sociology of Law: Judge as Mediator, 9 J. CLASSICAL Socio. 209 (2009).

${ }^{70} \mathrm{For}$ an English language overview of some of the criticism of the empirical basis of Weber's historical and cross-cultural generalizations, theoretical inconsistencies and political biases, see STANISLAV ANDRESKI, MAX WEBER's INSIGHTS AND ERRORS (2013).

${ }^{71}$ Wolfgang Schluchter, Handeln im Kontext: neue AbHandlungen ZU einem Forschungsprogramm im Anschluss an MaX Weber (2018). More specifically on legal doctrine, see Jens Petersen, MaX Webers ReCHTSSOZIOlOGIE UND DIE JURISTISCHE Methodenlehre (2008).

${ }^{72}$ I have used Weber's ideal typical method to study the Constitutional Courts in Germany and Hungary. See generally Christian Boulanger, Hüten, richten, Gründen: Rollen der Verfassungsgerichte in der Demokratisierung DeUtSCHLANDS UND UngaRns (2013).

${ }^{73}$ Das Rechtsdenken Pierre Bourdieus (Andrea Kretschmann ed., 2019); ANJA BÖNing, Jura STUdieren: EINE eXplorative Untersuchung im Anschluss an Pierre Bourdieu (2017); Michael Wrase, Rechtsinterpretation als soziale Praxis-eine rechtssoziologische Perspektive auf juristische Methodik, in POLITIK UND RECHT: UMRISSE EINES Politikwissenschaftlichen Forschungsfeldes 63-84 (Verena Frick, Oliver W. Lembcke \& Roland Lhotta eds., 2017).
} 
Bourdieu's concept of "habitus" is especially useful if we want to conceptualize doctrine as a social practice-meaning the sum of behaviors, attitudes, and ways of thinking that an individual has been socialized into as a part of a social group, such as lawyers, judges, professors, or bureaucrats. ${ }^{74}$ Bourdieu is skeptical of the doctrinal habitus ${ }^{75}$ but does not speak to the thesis of the indeterminacy of law. Instead, Bourdieusian insights are useful to identify social factors that affect the autonomy of legal discourse from within the legal field. ${ }^{76}$

The most individualistic approach surveyed here is the research on Behavioral Law and Economics that has gained prominence in Germany in the last couple of years following developments in economics in the United States. ${ }^{77}$ It is premised on the theoretical model of utility maximizing actors, but unlike the original rational choice model of the homo economicus with fixed preferences, it allows for corrections of that model, for example, via controlled experiments, or by using large legal datasets-which I will analyze in greater detail below. Even though the research in this tradition is empirical, it so far has remained largely unconnected to socio-legal studies, which has to do, inter alia, with the fact that this line of research is interested in empirical questions mainly to solve legal questions rather than advance social scientific theorizing. ${ }^{78}$ Law and Economics has traditionally regarded itself as an alternative to doctrinal analysis. ${ }^{79}$ Because there are many ways in which the production of legal doctrine can be analyzed from an economic perspective, even those skeptical of economic perspectives should not discount the heuristic value of these approaches. ${ }^{80}$

Radically opposed to approaches that look at individuals and groups is the Systems Theory perspective developed by Niklas Luhmann and Gunther Teubner. ${ }^{81}$ Such approaches understand law as an epistemic subject. From this perspective, law is a communicative system that creates its own reality, including the acting "persons," who appear only as "semantic artefacts" created by the system itself. System Theory views law as a self-referential system of communicative operations ${ }^{82}$ that differ from other communications by using the binary distinction

\footnotetext{
${ }^{74}$ Mikael R. Madsen \& Yves Dezalay, The Power of the Legal Field: Pierre Bourdieu and the Law, in An INTRODUCTION TO LAW AND SOCIAL THEORY (Reza Banakar \& Max Travers eds., 2002).

${ }^{75}$ For his characterization of jurists as the "gatekeepers of collective hypocrisy," see Pierre Bourdieu, Les juristes, gardiens de l'hypocrisie collective, in Normes JuridiQues et REgulation SOCIALE 195-99 (Francois Chazel \& Jacques Commaille eds., 1991).

${ }^{76}$ Mauricio García Villegas, On Pierre Bourdieu's Legal Thought, in DroIT ET Société 57 (2004).

${ }^{77} \mathrm{An}$ example of this is seen at the Max-Planck-Institute for Research on Collective Goods in Bonn. CHRISTOPH ENGEL, THE Proper SCOPE of Behavioral LAW ANd ECONOMics (2018), http://www.coll.mpg.de/pdf_dat/2018_02online.pdf (last visited July 24, 2019). For a central reference point of the U.S. literature, see generally Christine Jolls, Cass R. Sunstein \& Richard Thaler, A Behavioral Approach to Law and Economics, 50 StAn. L. ReV. 1471 (1998).

${ }^{78}$ Christoph Engel, Rechtswissenschaft als angewandte Sozialwissenschaft: Die Aufgabe Der

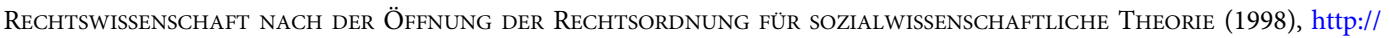
www.mpp-rdg.mpg.de/pdf_dat/9801.pdf (last visited May 23, 2020). Another reason might be continuing reservations of socio-legal studies towards Law and Economics. But the most important factor certainly is that publication in socio-legal and/or German legal journals is unattractive for Law and Economics scholars, who must publish in highly competitive, law and economy-focused journals to advance their careers.

${ }^{79}$ See Emanuel V. Towfigh, Empirical Arguments in Public Law Doctrine: Should Empirical Legal Studies Make a "Doctrinal Turn"?, 12 ICON 670 (2014).

${ }^{80}$ Dogmatic knowledge production, especially outside the courts, is subject to the rules of supply and demand. Depending on the context, certain types of doctrinal productions "pay off" more than others. On the one hand, financially-depending on the market for textbooks, commentaries, or expert opinions - and on the other hand, structurally, which is probably more important as a factor in the accumulation of reputational capital or career opportunities. It is also important to keep in mind the limits of an ahistorical focus on incentives when explaining the behavior of legal actors. See Craig Green, What Does Richard Posner Know About How Judges Think?, 98 CAL. L. ReV. 625, 626 (2010).

${ }^{81}$ See Ioannis Kampourakis, Empiricism, Constructivism, and Grand Theory in Sociological Approaches to Law: The Case of Transnational Private Regulation, in this issue.

${ }^{82}$ Gunther Teubner, Die Episteme des Rechts. Zu erkenntnistheoretischen Grundlagen des reflexiven Rechts, in WACHSENDE StAATSAUfGABEN-SinKende STEUERUNGSFÄHIGKeIT DES Rechts 114-55 (Dieter Grimm ed., 1990), in which Teubner emphasizes that "Law is communication and nothing but communication!" (p. 127).
} 
between "legal" and "illegal." ${ }^{83}$ For Luhmann, Rechtsdogmatik in its specific German characteristic is "one of several functionally equivalent solutions" of how the legal system is controlling its operations. ${ }^{84}$ Systems-theoretical legal analysis has often been criticized for taking tortuous detours to address the fact that "questions of interpretation are questions of power and sovereignty," ${ }^{25}$ a problem that "Critical Systems Theory" aims to address. ${ }^{86}$ System Theory is probably the best theory we have to describe the emergence of the precarious and, according to Luhmann, highly unlikely autonomy of law, via a process of functional differentiation. ${ }^{87}$ However, as Matthias Mahlmann has argued, System Theory is not particularly well-suited to identify the specific social forces or purposeful interventions-for example, by moral entrepreneurs - that very often drive real legal development. ${ }^{88}$

\section{Methods}

In German Sociology of law, different empirical methods have been used to look at what lawyers are doing. In the 1970s, Ekkehard Klausa called for an empirical "Sociology of Jurisprudence" and used survey research to gather information on law professors. ${ }^{89}$ More influential was Rüdiger Lautmann's study from 1972, which engaged in covert participant observation to study how first-instance court judges actually decide cases. ${ }^{90}$ After that, most work was theoretical and hermeneutic. It took roughly forty years before new empirical work in this tradition was produced, such as a study by Peter Stegmaier, who relied on interviews and overt participant observation to analyze how private and administrative judges deal with cases. ${ }^{91}$ But it was not the Sociology of Law that was most productive in this respect. ${ }^{92}$ Instead, the most influential works came from German Political Science, where partly interview-based research shed new light on doctrinal practices at the apex courts, such as studies by Uwe Kranenpohl and Oliver Lembcke on Justices of the Federal Constitutional Court, ${ }^{93}$ or by Britta Rehder on the interaction between the Federal Labor Court and labor law lawyers. ${ }^{94}$

\footnotetext{
${ }^{83}$ Niklas Luhmann, Law AS a Social System (Klaus A. Ziegert \& Fatima Kastner trans., 2008).

${ }^{84}$ Niklas Luhmann, Rechtssystem UND Rechtsdogmatik 18, 24 (1974). This is the "early" Luhmann, who does not yet use the language of autopoiesis.

${ }^{85}$ Eckard Bolsinger, Autonomie des Rechts? Niklas Luhmanns soziologischer Rechtspositivismus - Eine kritische Rekonstruktion, 42 Politische VierteljahressChrift 3, 21 (2001).

${ }^{86}$ See Marc Amstutz \& Andreas Fischer-Lescano, Kritische Systemtheorie: Zur Evolution Einer Normativen THEORIE (2014).

${ }^{87}$ LUHMANN, supra note 83 , at ch. 6 .

${ }^{88}$ Matthias Mahlmann, Katastrophen der Rechtsgeschichte und die autopoietische Evolution des Rechts, 21 ZEITSCHRIFT FÜR RECHTSSOZIOLOGIE 247, 275 (2000).

${ }^{89}$ See generally EKKehard Klausa, Deutsche und AMERIKanische RechtslehreR: Wege ZU EINER SOZIOLOGIE DER JURISPRUdEnZ. (1981). Klausa's "Program for a Sociology of Juridical Science" from 1975 had no lasting influence. See Ekkehard Klausa, Programm einer Wissenschaftssoziologie der Jurisprudenz, in WISSENSCHAFTSSOZIOLOGIE 100-21 (Nico Stehr \& René König eds., 1975).

${ }^{90}$ Because of the covert nature of the observation, the study was very controversial and would probably not pass today's research ethics review. Most of the stir it caused, however, was due to the fact that the study revealed how much the reality of judicial decision-making diverted from the official account of the legal process. RÜDIGER LAUTMANN, Justiz-die stille Gewalt: Teilnehmende Beobachtung und entscheidungssoziologische Analyse (Wiederabdruck ed. 2011).

${ }^{91}$ Peter Stegmaier, WisSen, WAS Recht IST: Richterliche ReCHTSPRAXIS AUS WisSENSSOZIOLOGISCH-ETHNOGRAFISCHER SicHT (2009).

${ }^{92}$ On this, see Christian Boulanger, Bundesverfassungsgerichtsforschung und Rechtssoziologie, 56 RECHT UND POLITIK (forthcoming 2020).

${ }^{93}$ Uwe Kranenpohl, Hinter DeM Schleier DES Beratungsgeheimnisses: DER Willensbildungs Und Entscheidungsprozess des Bundesverfassungsgerichts (2010); Oliver W. LembCKe, Hüter Der Verfassung: EINE INSTITUTIONENTHEORETISCHE STUDIE ZUR AUTORITÄT DES BUNDESVERFASSUNGSGERICHTS (2007).

${ }^{94}$ REHDER, supra note 52.
} 
Using survey research, interviews, or ethnographic methods ${ }^{95}$ can produce valuable empirical data. One reason why these works are so rare is that applying these methods involves a lot of additional effort and time-sometimes also financial resources-usually more than is required when doing desk-based research, not to mention the fact that German lawyers do not receive training in empirical methods. The general reluctance by legal professionals to publicly reflect on the various non-legal influences on their craft has been very strong in Germany, ${ }^{96}$ although this might be changing with new generations of increasingly interdisciplinary-minded legal scholars and practitioners. In many cases, however, only trained lawyers have access to, and can report from, what is going on inside the legal black box. ${ }^{97}$

An alternative approach is to return the focus to doctrinal text production. Recent literature has taken up concepts from literary studies to differentiate the ways in which textual data can be approached. On the one hand, "close reading" pays attention to the meaning of individual texts, and traces the development, diffusion, and transformation of doctrinal ideas against the social context in which they exist. An example of this kind of research in German constitutional law history would be Thomas Henne's and Arne Riedlinger's edited volume on the Lüth Decision of the German Federal Constitutional Court, ${ }^{98}$ which works out the historical context in which the doctrine of the "direct third-party effect" in German constitutional law was developed. Another example is Gunter Frieder's work on the competition between the Smend and Schmitt "schools" over doctrinal dominance in constitutional law scholarship in post-war Germany. ${ }^{99}$ Recently, Verena Frick traced the internal struggles within the German Association of Constitutional Law Teachers and the influence of these debates on constitutional law from a political science perspective. ${ }^{100}$ These works emphasize the importance of biographical detail, academic lineages, institutional competition, and historical events for the development of doctrinal thought. They call for the "historicization" of doctrine as opposed to the decontextualization and abstraction to which German legal thought tends. ${ }^{101}$

On the other hand, "distant reading" digests a large number of texts by having algorithms "read" the texts. ${ }^{102}$ Algorithmic reading of judicial or academic doctrinal texts is a newer branch of research into legal doctrine that differs from the traditional social scientific method of using texts as data with which to test hypotheses. ${ }^{103}$ Another method for inferring causal relationships

\footnotetext{
${ }^{95}$ For yet another approach, see micro-sociological work by Thomas Scheffer and others who have been comparatively studying interactions in German and UK courts. Thomas Scheffer, Kati Hannken-Illjes \& AleXander Kozin, Criminal Defence and Procedure: Comparative Ethnographies in the United Kingdom, Germany, and the United STATES (2010).

${ }^{96}$ See the preface of LAUTMANN, supra note 90 . There are also good reasons for this, such as keeping judicial deliberations confidential. KRANENPOHL, supra note 93, at ch. 5.

${ }^{97}$ See Hartmut Rensen, Wie funktioniert die Interpretation des Rechts in der Praxis?, in POLITIK UND RECHT: UMRISSE EINES POLITIKWISSENSCHAFTLICHEN ForSCHUNGSFELDES 41-62 (Verena Frick, Oliver W. Lembcke \& Roland Lhotta eds., 2017).

${ }^{98}$ See Das LÜth-Urteil in (Rechts-)historischer Sicht. Die Konflikte um Veit Harlan Und DIE Grundrechtsjudikatur des Bundesverfassungsgerichts, (Thomas Henne \& Arne Riedlinger eds., 2005).

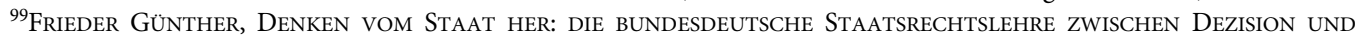
INTEGRATION 1949-1970 (2009). A different example from outside Germany would be recent work on the socio-historical genesis of the proportionality principle. See COHEN-EliYA \& PORAT, supra note 43.

${ }^{100}$ Verena Frick, Die StaAtsrechtslehre im Streit um Ihren Gegenstand: Die StaAts und VerfassungsDebatten SEIT 1979 (2018).

${ }^{101}$ DAS LÜTH-URTEIL IN (RECHTS-)HISTORISCHER SiCHT, supra note 98.

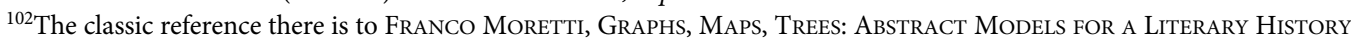
(2005). See Katherine Bode, The Equivalence of "Close" and "Distant" Reading; or, Toward a New Object for Data-Rich Literary History, 78 Mod. LANGUAGE Q. 77-106 (2017).

${ }^{103}$ This methodology is based on "coding" the texts. In other words, a researcher takes documents like judicial decisions and translates the texts into a number of static, mostly binary, variables. These variables are entered into a database; statistical methods are then used to calculate if the hypotheses can be confirmed or not. See, e.g., Sylvain Brouard \& Christoph Hönnige, Constitutional Courts as Veto Players: Lessons from the United States, France and Germany, EuR. J. POL. RES. 529 (2017); Benjamin G. Engst et al., Zum Einfluss der Parteinähe auf das Abstimmungsverhalten der Bundesverfassungsrichter - eine quantitative Untersuchung, 72 JURISTENZEITUNG 816 (2017).
} 
using a large number of texts is network analysis, which has been used, inter alia, to uncover citation networks in the jurisprudence of apex courts. ${ }^{104} \mathrm{~A}$ third often-used quantitative methodology is to use topic modeling algorithms, which have been defined as "statistical text mining or information retrieval methods used for uncovering the main themes underlying a collection of documents." ${ }^{05}$ This, for example, is used to show how rules of procedure affect the material content of decisions of the German Constitutional Court. ${ }^{106}$ Finally, I should mention recent efforts to bring together quantitative legal studies and legal linguistics, which will certainly have to be a part of a comparative study of doctrine. ${ }^{107}$

These text-based quantitative methodologies have been almost exclusively applied to digital text collections of judicial decisions. Unlike most other forms of legal data, collections of judicial decisions can, in many cases, be freely downloaded. In contrast, the access to digitized forms of legal scholarship is, in the majority of cases, encumbered by corporate paywalls and publisher's copyright - not to mention the complication of the fragmented state of ownership over the documents. This is probably the reason why legal doctrinal scholarship has not yet been the subject of much quantitative research. As legal scholarship increasingly moves to open access publishing and historical doctrinal scholarship falls into the public domain, we can expect growing opportunities for research on legal doctrinal scholarship. Given the availability of doctrinal "big data," we will be able to trace the emergence and development of doctrinal figures, trace citation networks, and academic lineages, as well as pursue other research questions that have occupied qualitative research for a long time.

\section{E. Conclusion and Outlook}

I have presented some of the theoretical and methodological approaches in German research on law that can be brought to bear on the interdisciplinary study of doctrine. The existing variety of theories and methods provides multiple angles from which to choose and explain historical and contemporary data. Combined with similar efforts in the UK and elsewhere, there is great potential for the comparative analysis of doctrinal knowledge production.

In the literature that I have surveyed, we have seen a diverse set of research questions, which could be brought together and pushed forward in a systematic interdisciplinary and comparative research program. One of them has been the question: To what extent do judicially or academically produced doctrinal rules determine judicial decisions? This concerns the varying degrees to which scholarship influences judges in their decision-making and whether this influence is openly acknowledged or not. ${ }^{108}$ However, it is important to ask what relationship exists between doctrinal practices and the character of the political regime in which it is embedded. ${ }^{109}$ Another, more

\footnotetext{
${ }^{104}$ See generally Mattias Derlén \& Johan Lindholm, Peek-A-Boo, It's a Case Law System! Comparing the European Court of Justice and the United States Supreme Court from a Network Perspective, 18 GERMAN L.J. 647 (2017); Jens Frankenreiter, Network Analysis and the Use of Precedent in the Case Law of the CJEU - A Reply to Derlén and Lindholm, 18 GERMAN L.J. 687 (2017); Niels Petersen \& Emanuel V. Towfigh, Network Analysis and Legal Scholarship, 18 GERMAN L.J. 695 (2017). For Germany, see Corinna Coupette, Juristische NetzWerkforschung. (2019).

${ }^{105}$ Luisa Wendel, Anna Shadrova \& Alexander Tischbirek, Variations in Prevalent Themes in the German Federal Constitutional Court's Decisions (unpublished manuscript on file with the author).

${ }^{106} I d$.

${ }^{107}$ See Hanjo Hamann \& Friedemann Vogel, Evidence-Based Jurisprudence Meets Legal Linguistics-Unlikely Blends Made in Germany, 2017 BYU L. REV. 1473 (2017).

${ }^{108}$ Neil Duxbury, in particular, has studied the relationship between courts and legal academia in the cases of the U.S., France, and the UK. See Neil Duxbury, Jurists AND Judges: An EsSAy On Influence (2001). Classical comparative works which also touch this question are John Philip Dawson, The Oracles of the Law (1968) and also RaOul Van Caenegem, Judges, Legislators and Professors: Chapters in European Legal History (1987).

${ }^{109}$ See generally the classic work by Mirjan R. DamašKa, The FaCES of Justice and State Authority: A Comparative Approach to the Legal Process (1986).
} 
theoretical line of inquiry, has been to ask about the function of law, and therefore legal-doctrinal practices in society. ${ }^{110}$ In what ways does doctrine support law's role as a tool of social control in the hands of the economically powerful, as scholars in the Marxian tradition have argued? ${ }^{111}$ How does doctrine, as a practice, preserve inequalities in terms of, for example, gender and race? ${ }^{112}$ And, on the contrary, in which cases can doctrinal practices be employed towards the aim of inducing progressive social change ${ }^{113}$ How does doctrine help sustain law's role as a medium of social integration envisioned by classical Sociology in the tradition of Durkheim and Weber? ${ }^{114}$ Finally, what do the widely divergent doctrinal practices in different jurisdictions tell us about law's function of stabilizing normative expectations postulated by System Theory? ${ }^{115}$

In addition, one can look at other theoretical perspectives that I have not mentioned. For example, it would be useful to connect the comparative Sociology of academic disciplines on one side, ${ }^{116}$ with the comparative study of legal scholarship, and of socio-legal studies, on the other. In addition, further empirical research is needed to determine how processes of doctrinal argumentation and persuasion actually work in the different legal arenas given the solid evidence of various cognitive biases that affect the "rationality" of legal argumentation and decision-making. ${ }^{117}$ This research would be crucial in covering the middle ground between the equally implausible, and largely abandoned, theoretical positions that maintain that doctrine either is the product of an internal "scientific" legal logic, or simply mirrors external influences—such as societal power relations, judges' ideological preferences, et cetera.

In German legal discourse, some argue that "through doctrinal work, objectification and value neutrality can and should be achieved." ${ }^{118}$ Most empirical theorists are doubtful of earlier claims that legal doctrine is actually able "to transform value judgements into questions of knowledge and truth." 119 As we have seen, whereas earlier social science theorizing, in particular in the United States, was convinced that legal arguments mattered little in the decision-making of courts, empirical research in the meantime has "established the very important point that

\footnotetext{
${ }^{110}$ See, e.g., Die FunKTION DES ReChtS IN DER MODERNEN GeSELlsChaft (Rüdiger Lautmann, Werner Maihofer \& Helmut Schelsky eds., 1970). I have examined this question in more detail. See Christian Boulanger, Die Soziologie juristischer Wissensproduktion, in INTERDISZIPLINÄRE RECHTSFORSCHUNG 173, 183-88 (Christian Boulanger, Julika Rosenstock \& Tobias Singelnstein eds., 2019).

${ }^{111}$ One text that has been influential in Germany and found an audience in the UK is KARL RENNER, THE INSTITUTIONS OF Private LaW and Their Social Functions (1949). For newer critiques of "Juridism" or the legal form, see Daniel LOICK, Juridismus: Konturen einer kritischen Theorie des Rechts (2017); see also Christoph Menke, KritiK Der Rechte (2015). None of these works are sociological in nature, however.

${ }^{112}$ Valentiner, supra note 47; Cengiz Barskanmaz, Rassismus, Postkolonialismus und Recht - Zu einer deutschen Critical Race Theory?, 41 Kritische Justiz 296 (2008).

${ }^{113}$ Many forms of civil rights litigation are aimed not only at affecting a certain outcome in a court case, but to establish judicial precedents that effectively change judicial doctrine. For Germany, where this is a rather recent topic, see Christian Boulanger \& David Krebs, Strategische Prozessführung, 39 Zeitschrift für Rechtssoziologie 1, 1-4 (2019); Alexander Graser, Strategic Litigation - oder: Was man mit der Dritten Gewalt sonst noch so anfangen kann, 10 Rechtwissenschaft 317 (2019). The U.S. literature - for example, by Austin Sarat, Stuart Scheingold, or Michael McCann—is well established. Newer works stress the fact that strategic litigation can also be used for aims that are contrary to the progressive agenda. See generally Amanda Hollis-Brusky, Support Structures and Constitutional Change: Teles, Southworth, and the Conservative Legal Movement: Support Structures and Constitutional Change, 36 L. \& SOC. INQUIRY 516 (2011).

${ }^{114}$ Mathieu Deflem, Sociology of Law: Visions of a Scholarly Tradition (2008).

${ }^{115}$ Or more precisely, of the expectation of expectations, see LUHMANN, supra note 84 , at ch. 3 .

${ }^{116}$ Michèle Lamont, How Professors Think: Inside the Curious World of Academic Judgment (2010).

${ }^{117}$ But see Daniel M. Klerman \& Holger Spamann, Law Matters - Less Than We Thought (2019), https://papers.ssrn. com/abstract $=3439526$ (last visited Nov. 22, 2019).

${ }^{118}$ Wahl, supra note 21 , at 129.

${ }^{119}$ Josef EsSER, VORVERSTÄNDNIS UND METHODENWAHL IN DER RECHTSFINDUNG: RATIONALITÄTSGRUNDLAGEN RICHTERLICHER ENTSCHEIDUNGSPRAXIS 98 (1972).
} 
doctrine does matter in future decisions." 120 How exactly this plays out in the interaction between courts, legal practitioners and the legal academy can be the subject of future interdisciplinary and comparative research. I have tried to show that doctrine, which many regard as arcane and/or boring by non-lawyers, is actually an interesting and important subject for comparative socio-legal research, and that it can elucidate some of the very marked legal-cultural differences between countries such as Germany and the UK.

\footnotetext{
${ }^{120}$ Emerson H. Tiller \& Frank B. Cross, What Is Legal Doctrine?, 100 Nw. UnIV. L. Rev. 517, 525 (2006).
}

Cite this article: Boulanger C (2020). The Comparative Sociology of Legal Doctrine: Thoughts on a Research Program. German Law Journal 21, 1362-1377. https://doi.org/10.1017/glj.2020.80 